\title{
FLUID EVOLUTION IN THE LA JOSEFINA AU-EPITHERMAL SYSTEM, MACIZO DEL DESEADO, SOUTHERN PATAGONIA, SANTA CRUZ, ARGENTINA
}

\author{
FRANCISCO JAVIER RIOS ${ }^{1}$, JAMES VIEIRA ALVES ${ }^{1}$, KAZUO FUZIKAWA ${ }^{1}$, ISIDORO B.A. SCHALAMUK ${ }^{2}$, \\ RAUL DE BARRIO ${ }^{2}$, MIGUEL DEL BLANCO ${ }^{2}$
}

\begin{abstract}
The La Josefina Au-Ag epithermal deposit is located in the Jurassic Macizo del Deseado volcano-sedimentary complex. In the present work mineralized vein formation fluids and dominant mineral stability conditions during their percolation have been studied. Primary fluids of aqueo-saline composition (without nitro-carbonic phases) have been identified. The earliest fluids related to the initial mineralizing stages (gold, adularia, tetrahedrite, galena and early quartz generations), with a salinity between 9 to $15 \mathrm{wt} \% \mathrm{NaCl}$ equivalent and temperatures near $250^{\circ} \mathrm{C}$. On the other hand, late primary fluids related to the latest quartz generations and (probably) hematite precipitation presented lower salinity $\left(<6 \mathrm{wt} \% \mathrm{NaCl}\right.$ equivalent) and temperatures near $200^{\circ} \mathrm{C}$. During the vein formation, an oscillation of pH (between 4.5 and $>5.5$ ) and of $\mathrm{O}$ activity (from $10^{-33 /-34}$ to $10^{-31 /-32}$ ) occurred. Gold must have precipitated as a consequence of boiling process at pressures near 9 to 36 bars. Adding to the $\log \left[f \mathrm{H}_{2} / f \mathrm{H}_{2} \mathrm{O}\right] \sim 2.9$ value the type of mineralization (gold-electrum-tetrahedrite), the small sulfide abundance, presence of adularia, range of salinity and temperatures and evidences of fluid boiling indicate the La Josefina district as a low sulfidation type deposit.
\end{abstract}

Keyword: Fluid Inclusion, La Josefina Au-Ag epithermal deposit, Patagonia-Argentina .

\section{INTRODUCTION}

The Macizo del Deseado, in southern Patagonia, Argentina (Fig. 1), gained a remarkable importance in the last two decades due to the discovery of numerous epithermal mineral districts such as Cerro Vanguardia, Manantial Espejo, La Josefina and Dorado Monserrat. Important $\mathrm{Au}$ and $\mathrm{Ag}$ deposits have been formed, and some of them are already being mined. In this study fluids related to the Au-Ag mineralized veins in the La Josefina district will be presented.

\section{REGIONAL GEOLOGY}

The Macizo del Deseado is a morphostructural province which developed in the upper Precambrian or Eopaleozoic and is represented by low to medium grade metamorphic rocks of the La Modesta Formation (Di Persia 1962). Small fluvial basins filled with Permian sediments of the La Golondrina (Archangelsky 1958) and La Juanita (Arrondo 1972) Formations and Triassic sediments of the El Tranquilo Formation (Di Persia 1965) were formed over these rocks.

From the upper Triassic to lower Jurassic an extensional system was established resulting in basaltic and andesitic lava flows of the Bajo Pobre Formation (Lesta \& Ferello 1972). From the mid Jurassic an intensive acidic volcanism commenced giving rise to a rhyolitic plateau which is now known as the Bahia Laura Group (Archangelsky 1967). The tensional regime established in areas of crustal instability culminated in the Atlantic Ocean opening (Uliana et al. 1985). This crustal extension process led to the formation of closed basins filled with continental sediments (Bajo Grande and Baqueró Formations) during the Cretaceous period.

During the Terciary and Quaternary, in the eastern part, basaltic flows intercalated with upper Oligocen marine (Patagonia Formation) and early Miocen continental sediments (Santa Cruz Formation) have been produced.

LOCAL GEOLOGY The oldest unity in the area is the La Modesta Formation, which crops out westward of the La Josefina Formation. It is formed mainly by grey to greenish micaceous-quartz schists and phyllites that occur in small outcrops. An angular unconformity separates the overlying La Modesta Formation from the mid-Jurassic basic to intermediate volcanic rocks of the Bajo Pobre Formation (Lesta \& Ferello 1972). The most extensive unit is represented by the Jurassic Bahia Laura Group (Stipanicic \& Reig 1957, Archangelsky 1967) wich is divided in the Chon Aike Formation and La Matilde Formation tuffs. The Chon Aike formation is divided into four members (Fernandez et al. 1996): Piedra Labrada (acidic ignimbrite flows, glassy lithoclastics, cristaloclastics and megabreccias); Cerro Jorge Paz (litho-glassyclastic ignimbrites with rare crystaloclasts and strongly lithoclastic brown-reddish ignimbrites); La Josefina (aphanitic, dacitic-rhyodacitic volcanites); and Maria Esther (vitrocrystaloclast ignimbrites and gray to darkviolet lavic facies).
Finally, covering large extensions in the northern part of the area, Tertiary and Quaternary basaltic levels complete the geological sequence.

MINERALIZATIONS The mineralized area extends over a strip of approximately $12 \times 1 \mathrm{~km}$, where the mineralizations are associated with vein stockworks and breccias (Schalamuk et al. 1998). In these structures, silica minerals plus primary minerals (native gold, electrum, galena, sphalerite, chalcopyrite, tetrahedrite, pyrite and marcasite) are common (Fig. 2). Those authors noticed that the sulphide content at the shallow levels of the deposit is low. Three generations of quartz have been identified: 1) the earliest is saccharoidal and forms most of the mineralized structures; 2 ) the second consists of translucent grains, and 3) the latest is represented by chalcedony or opal. In the ore, native gold is distributed in the limonite and coarse-grained quartz (or disseminated in fissures and boxwork) while electrum occurs as inclusions in coarse quartz grains. Sulfides are dominated by pyrite which occurs in two generations: an early one consisting of coarser grains that carrying noble metals and a later and subordinate one consisting of finer grains $(20-30 \mathrm{~mm})$. Galena is the main base metal sulfide and is associated with both saccharoidal and chalcopyrite as well as with quartz of the second generation. Sphalerite is subordinate and associated with galena whereas tetrahedrite was identified only as small inclusions in the sphalerite.

Finally, Schalamuk et al. (1998) described also barite, hematite, adularia and some supergene copper sulphides (covellite and chalcocite) in the paragenesis of the mineralized structures (Fig. 2). Cerussite-anglesite and mainly $\mathrm{Fe}$-hydroxides (limonite) exist as oxidized phases. Barite may even form veins in the central western part of the area. Hematite (specularite) forms radial aggregates of a few centimeters in diameter made up of needle like crystals. Adularia is an early mineral which presents two varieties: one is in contact with the host rock being partially replaced by quartz and the other forms in euhedral grains smaller than $500 \mathrm{~mm}$ with rhombohedral section and coeval with the saccharoidal quartz.

FLUID INCLUSION STUDY This study was done at the CDTN (Centro de Desenvolvimento da Tecnologia Nuclear) Fluid Inclusion Laboratory in a CHAIXMECA and a FLUID INC stages and the MacFlincor 0.9 software (Brown \& Hagemann 1994) compatible with a MacIntosh 5500 PC. Micro-Raman spectroscopy was performed at the Laboratory of Optics of the Department of Physics, Universidade Federal de Minas Gerais (UFMG). Samples from three different areas were studied: Estancia La Josefina, Veta Norte and Subsinter (Fig.1).

The Estancia La Josefina samples are from quartz veins cutting pyroclastic host rocks that occur near the farmhouse. In some places the veins present brecciated features and consist basically of several generations of quartz, hematite and micas. The two early generations 


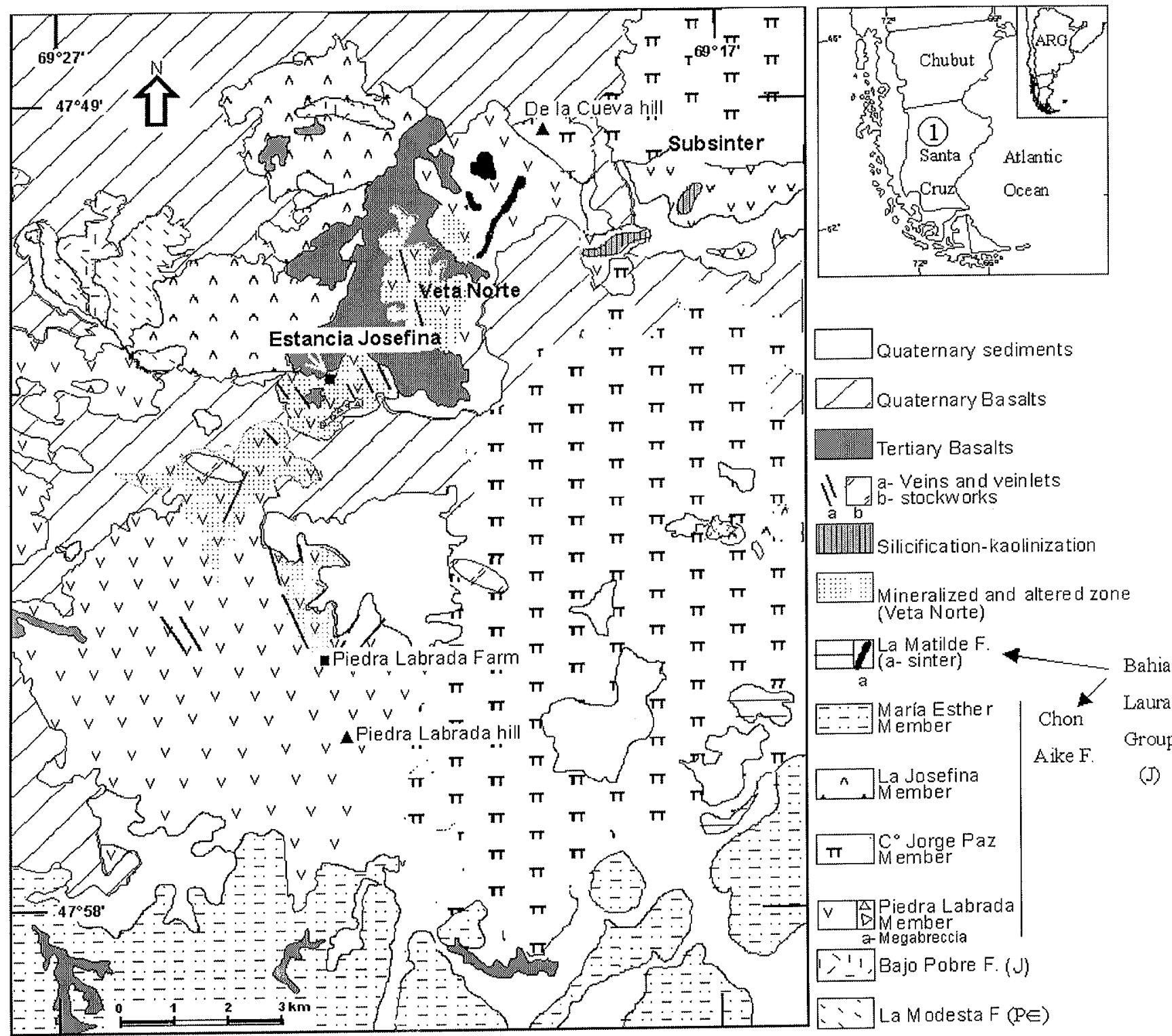

Figure 1-Geologic map of the La Josefina area. Modified from Schalamuk et al. (1998). Simbols: (1) Localization of the Macizo del Deseado; (Arg) Argentine; (Chubut, Santa Cruz) Provinces in Southern Patagonia; (F) Formation,

of quartz [quartz 1 (saccharoidal with solid inclusions) and quartz 2 (coarse)] are the dominant types in the veins. The third generation (quartz 3) occurs in the middle of veins enveloping the previous generations. It presents a feather-like texture that probably resulted from the recrystallization of chalcedony (Sander \& Black 1988). Hematite crystallized toward the end of quartz-1 precipitation. Quartz crystals prior to the vein formation (magmatic?) and limonite (from pyrite) have been found in the pyroclastic matrix.

The Veta norte samples are from hydrothermal veins consisting of quartz- 1 and 2 and needle-shaped hematite crystals. The quartz crystals often present primary fluid inclusions (FI) defining growth lines. Barite together with opal and drusy quartz form pockets and are present as late minerals.

The Subsinter area is located at the northeastern end of the district (Fig. 1). Samples studied are from quartz veins cutting host pyroclastic rocks that has two generations of quartz similar to quartz-2 and quartz3 from Estancia La Josefina.

INCLUSIONS TYPE Petrography and Microthermometry MELTINCLUSIONS They are rare and found in quartz from host pyroclastic rock, being two-phased, rounded and of $\sim 20 \mathrm{~mm}$ in size.
TYPE P1 FLUID INCLUSIONS They are primary, two phased ( $\mathrm{L}+\mathrm{V}$, no solid phases) smaller than $10 \mu \mathrm{m}$ and hosted by quartz- 1 from Estancia La Josefina. The degree of filling varies from 0.1 to 1.0 suggesting the occurrence of boiling. Phase changes during cryometry do not indicate presence of carbonic phases. This was confirmed by micro-Raman spectroscopy (nitro-carbonic and $\mathrm{H}_{2} \mathrm{~S}$ phases were not detected). Ice melting temperatures $\left(\mathrm{Tm}_{\mathrm{CE}}\right)$ were in the -6 to $-11^{\circ} \mathrm{C}$ range implying salinity between 9.2 to $15 \mathrm{Wt} \% \mathrm{NaCl}$ equivalent. FI populations with larger variation in the degree of filling present the lower salinity. Heating tests yielded homogenization temperatures (Th) between 220 to $280^{\circ} \mathrm{C}$.

TYPE P2 FLUID INCLUSIONS These are primary two-phase $(\mathrm{L}+\mathrm{V}$ inclusions), irregular in shape and $<5$ to $40 \mu \mathrm{m}$ in size present in quartz-2 from Estancia La Josefina, Veta Norte, and Subsinter veins (Fig.3). The degree of filling in Type P2 FI studied at Estancia La Josefina varies from 0.0 to $\sim 0.9$ (Fig. $3 \mathrm{~A}$ ) suggesting again the occurrence of boiling process. This process, nevertheless, was not observed at the Veta Norte and Subsinter (Fig. 3B) areas. Some pseudo-secondary FI present randomly captured birefringent solid phases. The micro-Raman OH peaks of these solids are indicative of muscovite. The cryometry does not show evidence of carbonic phases. 


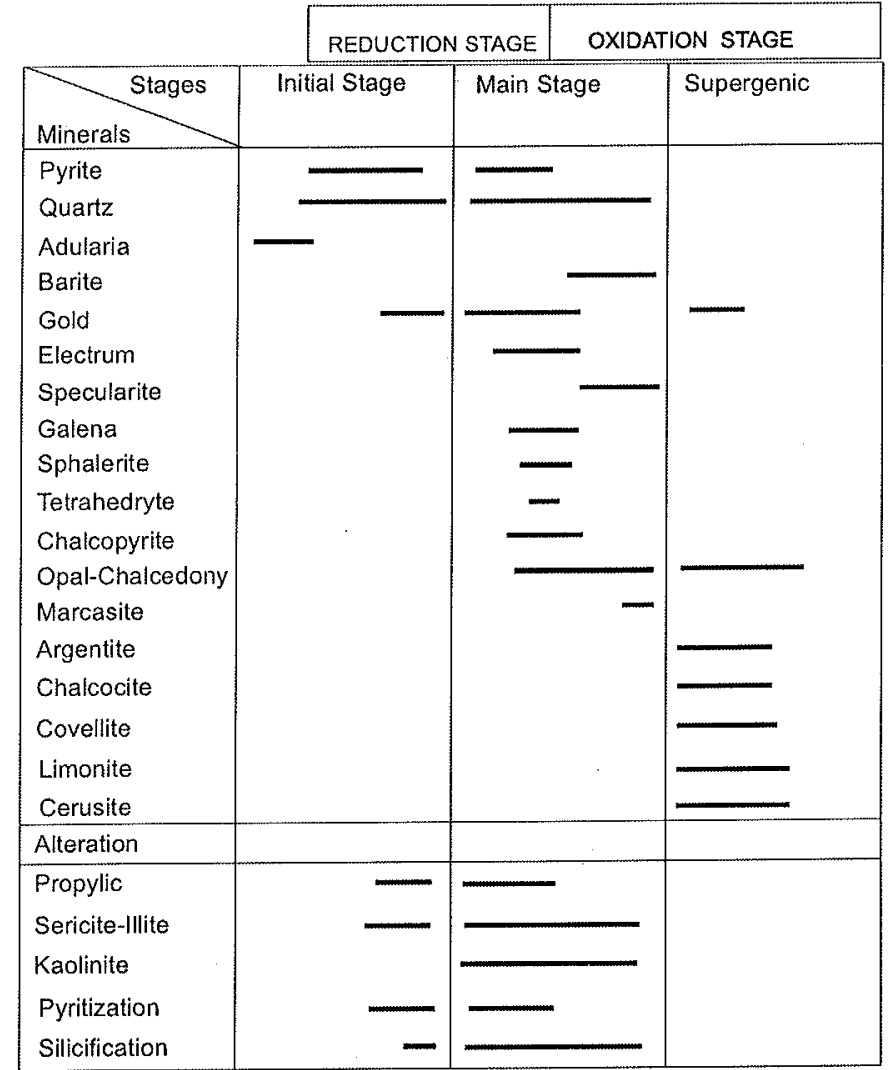

Figure 2 - Paragenetic sequence in the La Josefina area from Schalamuk et al. 1998).

Tm between 0.0 and $-3.6^{\circ} \mathrm{C}$ indicate low salinity of the aqueous fluid $(0.0$ to $5.8 \mathrm{wt} \% \mathrm{NaCl}$ equiv. $)$. The Th shows a general dispersion of values, but two intervals are more frequent: 210 to $290^{\circ} \mathrm{C}$ and 170 to $200^{\circ} \mathrm{C}$. The latter corresponds to FI with solid phases.

TYPE P3 FLUID INCLUSIONS These are primary FI associated with growth surfaces of quartz-3 veins from Estancia La Josefina. They are one to two-phase aqueous inclusions presenting irregular shape and evidences of necking down. Solid phases are scarce. $\mathrm{Tm}_{\mathrm{icc}}$ occur between -1.0 and $-0.1^{\circ} \mathrm{C}$ indicating salinity of $0.18-1.74 \mathrm{wt} \% \mathrm{NaCl}$ equivalent. Th are in the 240 to $260^{\circ} \mathrm{C}$ range.

TYPE P4 FLUID INCLUSIONS These are primary FI in barite from Veta Norte samples. They are single phased dark and rounded FI with 10 to $40 \mu \mathrm{m}$ in size and high relief. $\mathrm{Tm}_{\mathrm{ice}}$ between -2.0 to $-3.0^{\circ} \mathrm{C}$ indicate 4 to $5 \mathrm{wt} \% \mathrm{NaCl}$ equivalent salinity.

TYPE S1 FLUID INCLUSIONS These are secondary FI in quartz 2 from Estancia La Josefina and Veta Norte. They usually contain three phases $(\mathrm{L}+\mathrm{V}+\mathrm{S})$ due to the very common presence of a trapped birefringent solid (micas?). Their behavior under cooling and heating are similar to type $\mathbf{P} 2$ inclusions.

DISCUSSION Fluid evolution FI data indicate that the mineralized veins were formed from aqueous-saline fluids of variable salinity in a relatively narrow temperature interval (Fig. 4).

Quartz-1 crystallized from a boiling fluid with moderate salinity $(<$ $16 \mathrm{wt} \% \mathrm{NaCl}$ equivalent). Paragenetic relations (Schalamuk et al. 1998) suggest a temporal overlap during sphalerite and quartz-1 precipitation, so that both minerals must have precipitated from the same fluid. FI study in sphalerite from Manantial Espejo (Rios et al. 1998), which is another epithermal district in Macizo del Deseado, points to a fluid with similar characteristics to type P1 fluid described here. In low sulfidation epithermal environments, fluids with $10-15 \mathrm{w} \%$ $\mathrm{NaCl}$ equivalent concentrations are characteristic of depositional periods where $\mathrm{Ag}$ was dominant over $\mathrm{Au}$ in a rate up to $\mathrm{Ag} / \mathrm{Au}>100$ (Hedenquist \& Lowerstern 1994). This process happens as an increase

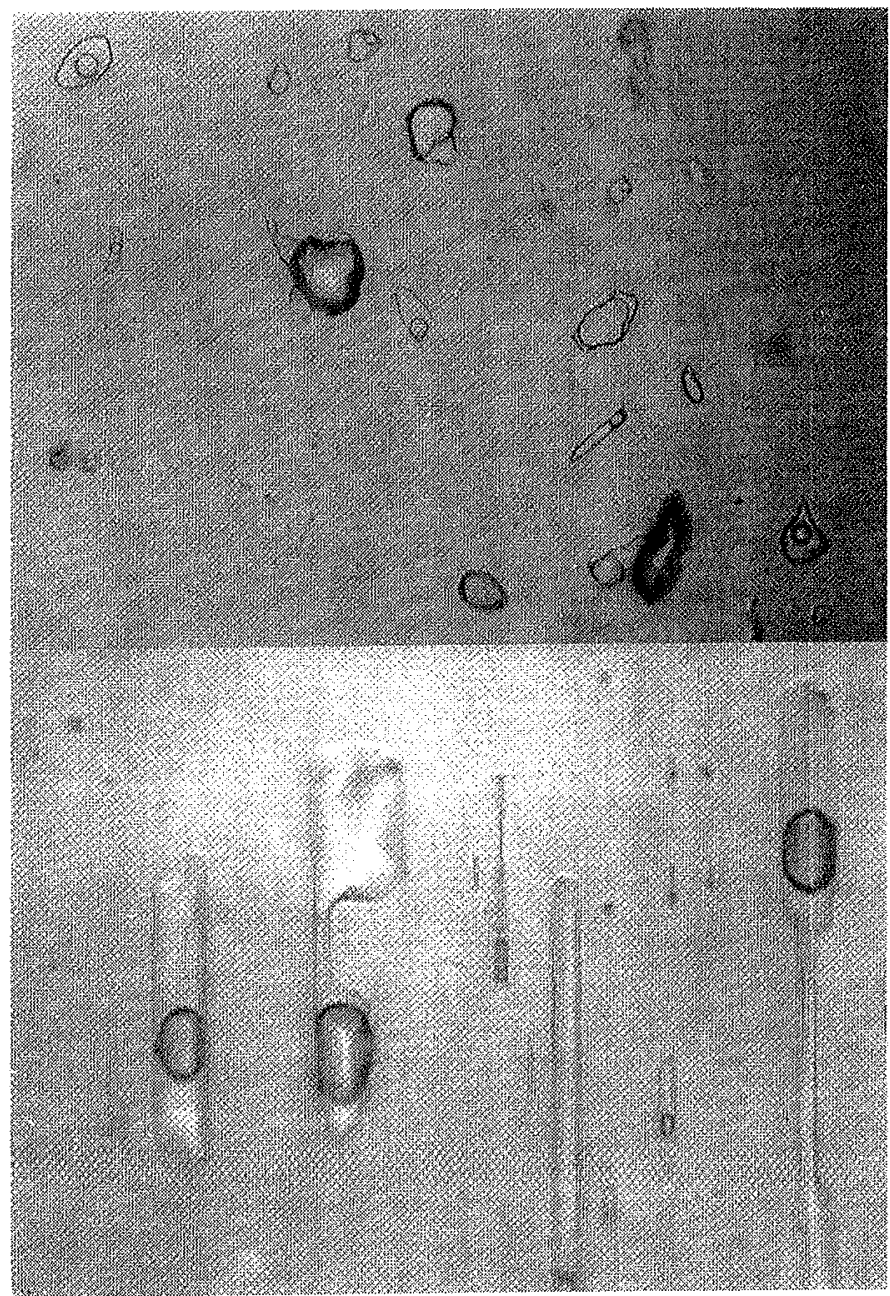

Figure 3 - Photomicrographs of selected FI of the La Josefina area. A: Primary-boiling Type P2 FI (Veta Norte, qtz-2); B: Primary tube-like Type P2 FI (Subsinter qtz-2). Bar: $10 \mu \mathrm{m}$.

in Au solubility due to the increase in salinity and lowering of fluid temperature (O'Neil \& Silberman 1974, Henley 1993, Hedenquist \& Lowerstern 1994) which could be the case for La Josefina and Manantial Espejo deposits.

During crystallization of quartz- 2 an evident dilution of fluids occurred, although the thermal and boiling conditions of the system remained unaltered. According to Fournier (1983 and 1985) the quartz solubility increases as salinity rises at temperatures around $300^{\circ} \mathrm{C}$. This fact could explain why quartz-1 (FI with higher salinity) is less abundant than quartz-2 (FI with lower salinity) in the veins.

Feather like quartz (recrystallized chalcedony?) was formed later from low salinity fluids due probably to silica oversaturated fluids (Rimstidt 1997). Sander \& Black (1988) call attention to the validity of FI microthermometric data from feather like quartz, as they would be pseudo-primary or modified, originated during post-depositional changes, and probably do not reflect the true thermal conditions of precipitation. Barite has crystallized much later from a very low salinity aqueous fluid at temperatures, probably lower than $100^{\circ} \mathrm{C}$. Finally, although $\mathrm{CO}_{2}$ and $\mathrm{H}_{2} \mathrm{~S}$ have not been detected during microthermometry and micro-Raman studies, crushing tests showed bubbles of gases, besides water vapor, associated with the fluids of the silicification stage.

Pressure Estimates The aqueous fluid eutectic temperature that precipitated quartz at La Josefina could not be determined. Nevertheless, these solutions which belong to the $\mathrm{NaCl}-(\mathrm{KCl})-\mathrm{H}_{2} \mathrm{O}$ system are similar in salinity and temperature to those found in quartz in the nearby Manantial Espejo District (Rios et al. 1998). Thus, barometric estimates based on FI data of Josefina using the $\mathrm{NaCl}$ - 


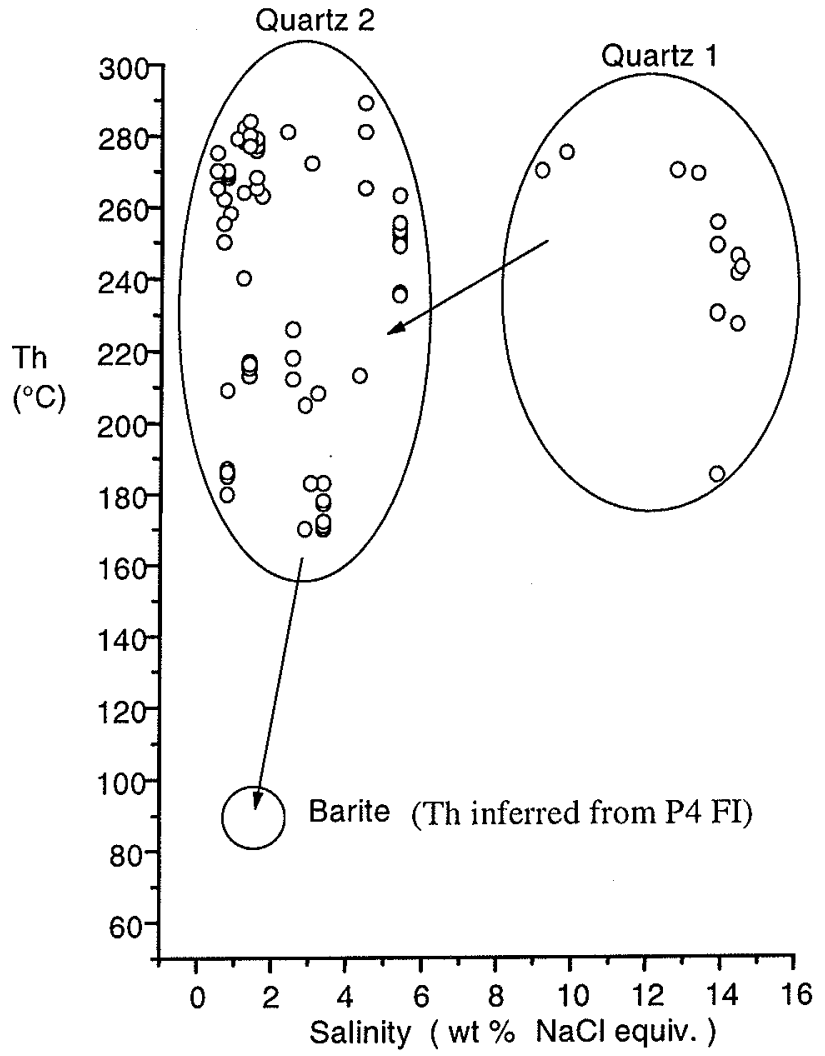

Figure 4 - Th $x$ Salinity diagram showing the evolution path followed by veinforming brines in the La Josefina district.

$(\mathrm{KCl})-\mathrm{H}_{2} \mathrm{O}$ system suggest that quartz-1 was formed under a minimum pressure range of 24 to 36 bars while quartz-2 was formed between 9 and 20 bars, characterizing an almost superficial condition.

Boiling It is considered to be one of major causes for gold precipitation in epithermal environments (Henley 1990 and 1993). FI data point to the occurrence of boiling in type P1 and P2 fluids. The presence of adularia is another indication of boiling (Henley 1993, Dong \& Morrison 1995). Thus, gold precipitation at La Josefina, can be interpreted as a result of this process. Fluid dilution observed between the end of quartz-1 precipitation and the beginning of quartz2 precipitation may have been a subordinate process for gold ore formation which was favored by a decrease in the temperature of mineralizing solutions of at least $50^{\circ} \mathrm{C}$. The role of other factors such as changes in $\mathrm{pH}$, pressure, and $\mathrm{H}_{2} \mathrm{~S}$ concentrations have not been evaluated.

Evolution Stages - Activity Conditions The paragenetic sequence in mineralized veins (Schalamuk et al. 1998) at La Josefina allows us to distinguish two stages. The first, of reducing character, started after the crystallization of adularia and extended over the pyrite, tetrahedrite, chalcopyrite, galena, quartz-1 and sphalerite formations. This mineral assemblage enabled us to limit the field of stability of pyrite (in relation to $\mathrm{S}_{2}$ and $\mathrm{O}_{2}$ activities). For that purpose the average Th $\left(\sim 250^{\circ} \mathrm{C}\right)$ of type P1 FI from quartz-1 was used (quartz-1 is the mineral probably coeval with late pyrite). The data are plotted on a $\log \mathrm{a}_{\mathrm{s}} \times \log \mathrm{a}_{2}$ diagram at $250^{\circ} \mathrm{C}$ (Fig.5). To set the position of $\mathrm{La}$ Josefina pyrite on the $y$-axis of this diagram the $\mathrm{FeO}$ content in sphalerite $(0.193 \mathrm{~mol} \%)$ was calculated from Schalamuk et al. (1998) microprobe data. To set the position on the $\mathrm{x}$-axis the presence of $\mathrm{K}$ mica in the paragenetic sequence was considered. As this mica is present as solid phase in type P2 FI, it precedes the formation of quartz-2. Furthermore, Schalamuk et al. (1998) recognized the occurrence of sericite coeval with late pyrite and, therefore, with quartz-1. To set the position of K-mica, considering that at La Josefina the sulphide concentration at surface is very low, the K-mica-kaolinite boundary corresponding to $\Sigma \mathrm{S}=-3$ was chosen. The results indicate

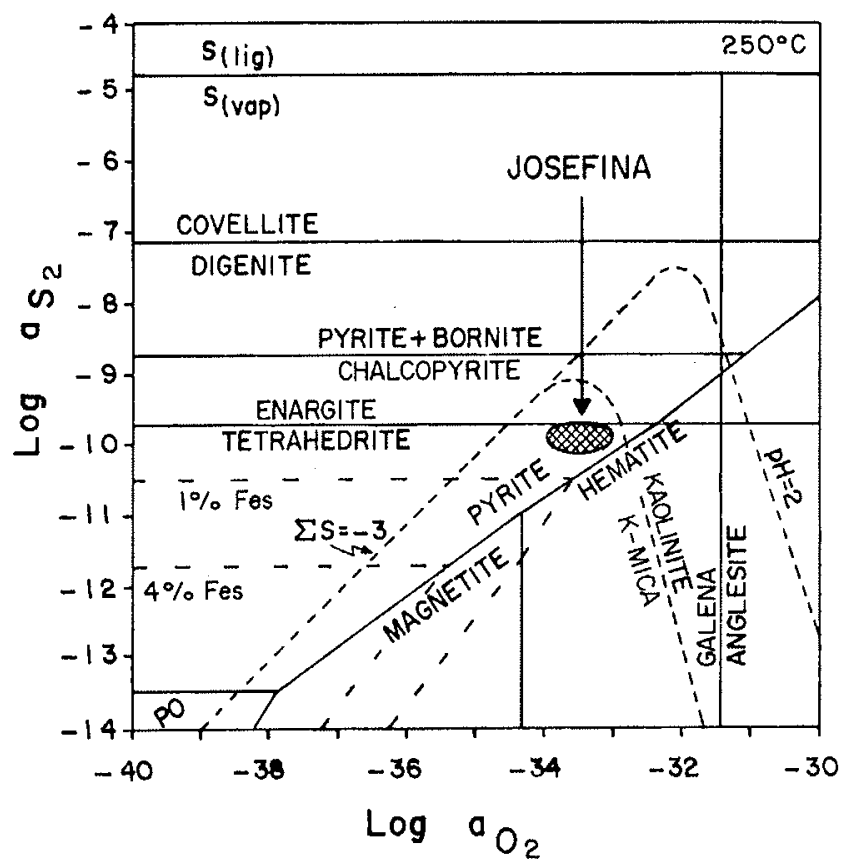

Figure $5-\log a_{S 2} X \log a_{O 2}$ diagram at $250^{\circ} \mathrm{C}$, showing the stability fields of minerals in epithermal environments (Hayba et al. 1985). To locate the position of La Josefina co-precipitation of pyrite, tetrahedrite and $K$-mica and the sphalerite FeS mol\% were considered.

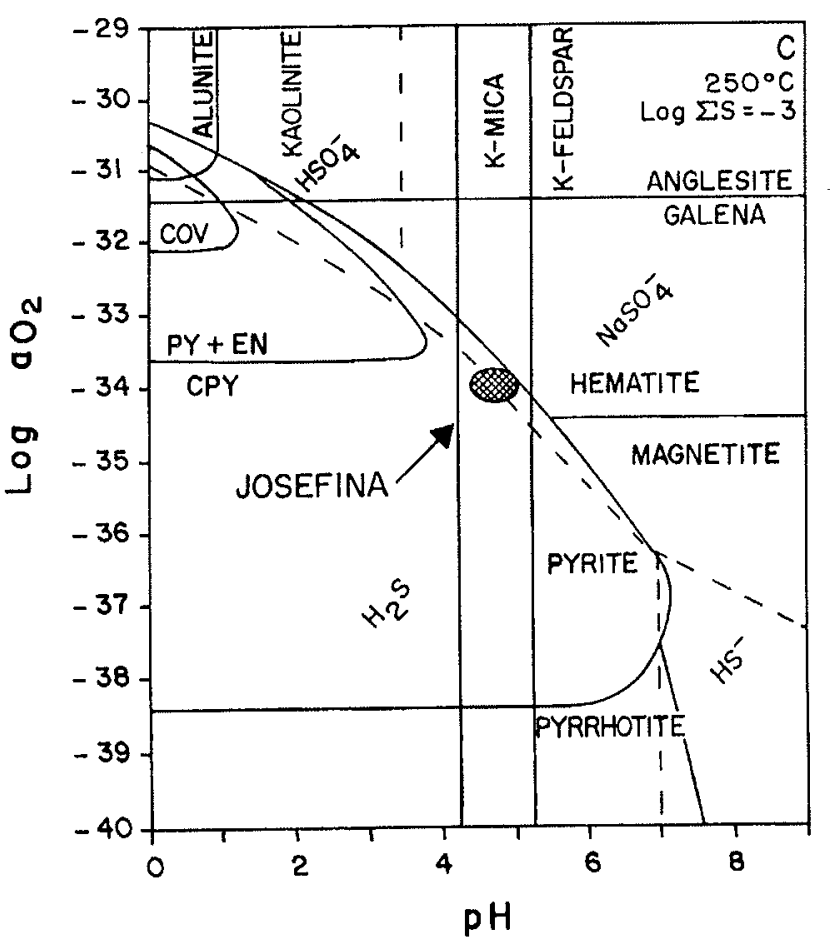

Figure $6-\log a_{02} \mathrm{X} p H$ diagram at $250^{\circ} \mathrm{C}$ and low $\mathrm{S}$ concentration $(\log \ddot{a} \mathrm{~S}=-$ 3) (Hayba et al. 1985). The position of La Josefina paragenetic sequence (Fig. 2) and $\log$ a $\mathrm{O}_{2}$ (from fig. 5) were considered. 


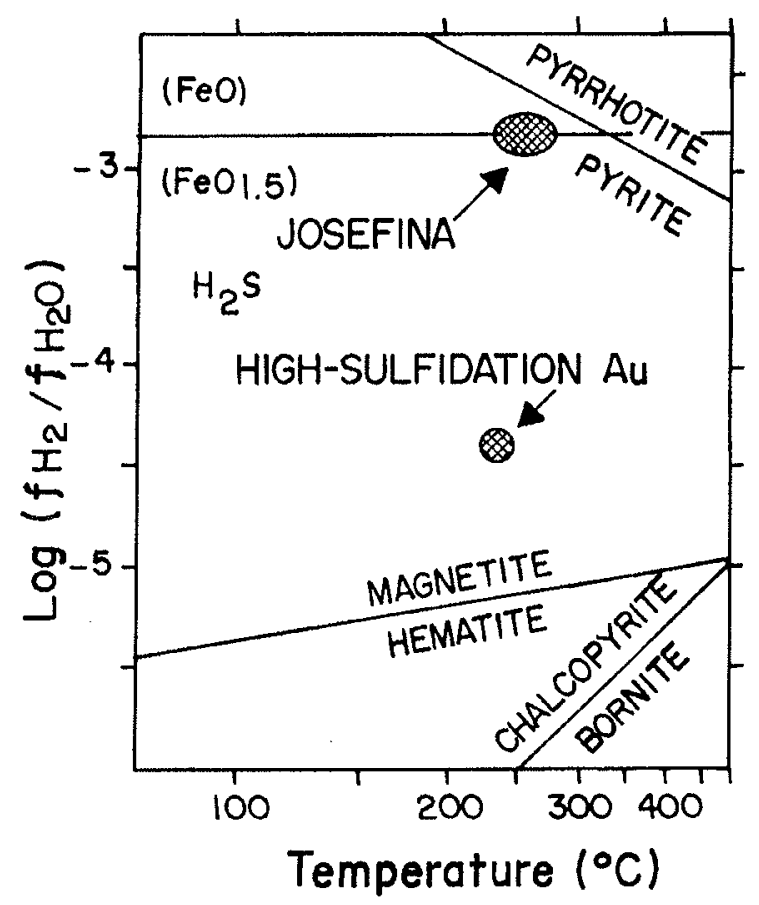

Figure 7 -Redox $x$ Potential $x$ Temperature for epithermal fluids (modified from Hedenquist et al. 1997). The values obtained for La Josefina are: Redox Potential $=2.9$ and Th $(Q z-1)=230-280^{\circ} \mathrm{C}$. Fluids from La Josefina plot near the pyrrhotite stability field, coincidental with other low sulfidation. auriferous epithermal deposits.

that the solutions precipitating pyrite, electrum, and probably, part of the gold at $\mathrm{La}$ Josefina during the reducing stage, presented low $\mathrm{a}_{02}$ near $10^{-33} / 10^{-34}$ and $\mathrm{a}_{\mathrm{S} 2}$ around $10^{-10}$. Following the reducing stage, a slight increase in oxygen concentration occurred, leading to hematite and late quartz precipitation, starting an "oxidizing" stage. The use of $\log a_{\mathrm{S} 2} \times \log \mathrm{a}_{\mathrm{O} 2}$ diagrams (Hayba et al. 1985, Heald et al. 1987) permitted the inference that during this stage the $\mathrm{a}_{\mathrm{O} 2}$ values increased to near $10^{-31 /-32}$.

pH and $\mathbf{f H}_{2} / \mathbf{f H}_{2} \mathbf{O}$ relations The $\log \mathrm{a}_{\mathrm{O} 2} \times \mathrm{pH}$ diagram for $\Sigma \mathrm{S}$ $=-3$ at $250^{\circ} \mathrm{C}$ was used to estimate the $\mathrm{pH}$ of the aqueous solutions (Fig.6). The results indicate that during the formation of veins the $\mathrm{pH}$ of mineralizing fluids varied from 4.5 to 5.5 . According to Hedenquist et al. (1997) adularia is the indicator for alkaline $\mathrm{pH}$. It can be concluded, therefore, that $\mathrm{pH}$ values around 6 in epithermal $\left(250^{\circ} \mathrm{C}\right)$ environments must represent alkaline conditions. However, during precipitation of hematite, quartz-2 and chlorite, the $\log a_{\mathrm{O} 2} \times \mathrm{pH}$ diagrams (Fig. 6) points to $\mathrm{pH}$ higher than 5.5 .

To fix the position of the La Josefina deposit in relation to other low and high sulfidizing epithermal deposits the $\log \left(\mathrm{fH}_{2} / \mathrm{fH}_{2} \mathrm{O}\right) \times$ temperature $\left({ }^{\circ} \mathrm{C}\right.$ ) diagram (Hendequist et al. 1997) was used (Fig. 7). For $\log \left(\mathrm{fH}_{2} / \mathrm{fH}, \mathrm{O}\right)$ determinations the $\mathrm{H}_{2} \mathrm{O}(\mathrm{l})=\mathrm{H}_{2}(\mathrm{~g})+1 / 2 \mathrm{O}(\mathrm{g})$ reaction, where $\log \mathrm{K}=7.6-14564.13 / \mathrm{T}$. $\left({ }^{\circ} \mathrm{K}\right.$ ) (Henley et al., 1984), and the $\log \mathrm{a}_{\mathrm{O} 2}$ values obtained from Fig 5 diagrams were used. For temperature, quartz- 1 Th average values $\left(250^{\circ} \mathrm{C}\right)$ were used. Quartz1 is contemporaneous with gold precipitation. The results indicate that the La Josefina deposit overlaps the field of the low sulfidation $\mathrm{Au}-\mathrm{Ag}$ deposits $\left(\log \left[\mathrm{fH}_{2} / \mathrm{fH}_{2} \mathrm{O}\right]=2.9\right)$, in a reducing environment and within the pyrite and $\mathrm{H}_{2} \mathrm{~S}$ stability fields. Under these prevailing physicochemical conditions, pyrrhotite saturation in the La Josefina deposit was expected.

Complex lons Looking at activity, fugacity, $\mathrm{pH}$, and temperature diagrams used in the present study, the conditions delimited at La Josefina overlap the $\mathrm{H}_{2} \mathrm{~S}$ field stability. This condition suggests that the ion complex carrying $\mathrm{Au}$ in solution was $\mathrm{Au}(\mathrm{HS})$, according to the reaction $\mathrm{Au}+2 \mathrm{H}_{2} \mathrm{~S} \Leftrightarrow \mathrm{Au}\left(\mathrm{H}_{\mathrm{S}}\right)_{2}+\mathrm{H}^{+}+0.5 \mathrm{H}_{2}$ proposed by Henley (1990). Temperatures $<350^{\circ} \mathrm{C}$ favor the formation of Au sulphide complex (Gammons \& Williams-Jones 1997). Au hydrosulfide complexes are known to be efficient gold carriers in hydrothermal solutions (Henley 1990) under relatively reducing, low salinity, in equilibrium with pyrite conditions (Seward 1984; Phillips \& Powell 1992).

CONCLUDING REMARKS The mineral content (electrum + gold + tetrahedrite), in addition to textures, low-medium fluid salinity, temperature average $\left(-250^{\circ} \mathrm{C}\right.$, quartz $)$, presence of adularia, values of $\log \left(\mathrm{fH}_{2} / \mathrm{fH}_{2} \mathrm{O}\right)=2.9$, little abundance of sulfides and evidences of fluid boiling are indicators for the inclusion of the La Josefina District in the category of adularia-sericite (Heald et al. 1987, Marcoux 1995, among others) low sulfidation (Hedenquist \& Lowenstern 1994, Hedenquist et al. 1997) epithermal deposits. These deposits are generally located on marginal zones of volcanic centers, of lode types, formed within limited $\mathrm{pH}$ range (almost neutral) under hydrostatic pressures and may be associated with geothermal activities.

Acknowledgements To Drs. J.M. Correia Neves (CDTN/ CNEN) and E. Bilal (EMSE-France) for their comments and suggestions; to FAPEMIG (Process 1046/95); to FOMICRUZ Provincial Mining Company (Santa Cruz, Argentina) for the support during field work; to Dr. M.S.S. Dantas (Física-ICEX-UFMG) for her support during micro-Raman analysis. To three anonymous referees of RBG for the critical review of the manuscript.

\section{References}

Archangelsky S. 1958. Estudio geológico y paleontológico del Bajo La Leona (Santa Cruz), Argentina. Acta Geológica Lilloana, Tucumán, II: 5-133.

Archangelsky S. 1967. Estudio de la Fm. Baqueró Cretácico inferior de Santa Cruz, Argentina. Revista Museo de La Plata (nueva serie) V, Paleontología, p. 32.

Arrondo O. 1972. Estudio geológico y paleontológico en la zona de Estancia La Juanita y alrededores, provincia de Santa Cruz, Argentina. Revista del Museo de La Plata, VII Paleontología, 43: $1-194$.

Brown P.E. \& Hagemann S.G. 1994. Mac Flincor: A computer program for fluid inclusion data reduction and manipulation. In: De Vivo, F. \& Frezzotti, M (Eds): Fluid

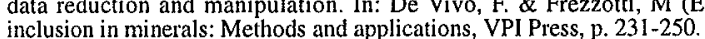

Di Persia C.A. 1962. Acerca del descubrimiento del Precámbrico en la Patagonia Extraandina (Prov. de Santa Cruz). In: Primeras Jornadas Geológicas Argentinas, Actas II: Buenos Aires. p. $65-68$

Di Persia C.A. 1965. Presencia de sedimentos triásicos en el Ambiente del Deseado. In: II Jornadas Geológicas Argentinas, Actas, Buenos Aires 2: 147-154.

Dong G. \& Morrison G.W. 1995. Adularia in epithermal veins, Queensland: morphology, structural state and origin. Mineralium Deposita, 30:11-19.

Fernández R.R, Echeveste H., Echavarría L., Schalamuk I. 1996. Control volcánico y tectónico de la mineralizacion epitermal del área de La Josefina, Macizo de Deseado, Santa Cruz, Argentina. In: XIII Congreso Geológico Argentino y II Congreso de Exploración de Hidrocarburos, Actas III: $41-54$

Fournier R. O. 1983. A method of calculating quartz solubilities in aqueous sodium chloride solutions. Geochimica et Cosmochimica Acfa, 47: 579-586.
Fournier R O 1985 . The behavior of silica in hydrothermal systems. Reviews in Economic Geololy, (2): 45-61.

Gammons C.H. \& William Jones A.E. (1997) Chemical mobility of gold in the porphyryepithermal environment. Economic Geology, 92: 45-59

Hayba D.O., Bethke P.M., Heald P., Foley N.K. 1985. Geologic, mineralogic, and geochemical characteristics of volcanic hosted epithermal precious metal deposits. In: Berger B.R. \& Bethke M. (Eds) Geology and geochemistry of epithermal systems. Reviews in Ecomic Geology, 2, p. 129-162.

Heald P., Foley N.K., Hayba D.O. 1987. Comparative anatomy of volcanic-hosted epithermal deposits: acid-sulfate and adularia-sericite type. Economic Geology, 82:126.

Hedenquist J.W. \& Lowenstern H. 1994. The role of magmas in the formation of bydrothermal ore deposits. Nature, 370: $519-527$

Hedenquist JW. Izawa E. Arribas A., White N.C. 1997. Epithermal gold deposits: Styles, characteristics, and exploration. The Society of Resource Geology; Japan, Special Publication Number 1 .

Henley R.W., Truesdell A.K., Barton P.B. 1984. Fluid mineral equilibra in hydrothermal systems. Reviews in Economic Geology, 1,267p.

Henley R.W. 1990 . Ore transport and deposition in epithermal environments. In: Herbert, H.K. \& Ho, S. (Eds) Stable isotope and fluid processes in mineralization. Geology Departament of the University of Western Australia. Publication n. 23, p. 51-69

Henley R.W. 1993. Epithermal gold deposits in volcanic terraines. In: R.P. Foster, Gold metallogeny and exploration, Chappman \& Hall, London 1993, p.133-164. 
Lesta P. \& Ferello R. 1972. Región extrandina de Chubut y norte de Santa Cruz. In: Leanza, A. F. (Ed), Geología Regional Argentina. Academia Nacional de Ciencias, Córdoba, p.601-653

Marcoux E. 1995. Gold and volcanoes: epithermal gold deposits, a review. C. R. Acad. Sci. Paris, t.321, serie IIa, p.723-735.

O'Neil J.R. \& Silberman M.L. 1974. Stable isotope relations in epithermal Au-Ag deposits. Economic Geology, 69: 902-909.

Phillips G.N. \& Powell R. 1992. Gold only provinces and their common features. Economic Research Unit. James Cook University of North Queensland, Townsville. EGRU Contribution 43, 27p.

Rios F J Alves JV Fuzikawa K Schalamuk I B A 1998. Estudio de inclusiones fluidas en el distrito autífero de Manantial Espejo, Santa Cruz, Argentina. In: IV Reunión de Mineralrito autffero de Manantial Espejo, Santa Cruz, Argentina.

Rimstidt J.D. 1997. Gangue mineral transport and deposition. In: H.L. Barnes (Ed) Geochemistry of hydrothermal ore deposits, p. 487-515.

Sander M.V. \& Black J.E. 1988. Crystallization and recrystallization of growth-zoned vein quartz crystals from epithermal systems: Implications for fluid inclusions studies. Economic Geology 83:1052-1060.
Schalamuk I.A. Del Blanco M.A., de Barrio R.E., Etcheverry R.O., Marchionni D.S., Tessone M.O. 1998. Características mineralogicas de la Paragénesis epitermal del prospecto La Josefina Macizo del Deseado, Provincia de Santa Cruz. In IV Reunión prospecto La Josefina, Macizo del Deseado, Provincia de Santa Cruz. In
de Mineralogia y Metalogenia, Bahia Blanca, Argentina, p. 259-266.

Seward T.M. 1984. The transport and deposition of gold in hydrothermal systems. In: R.P. Foster (Ed) Gold' 82, The geology, geochemistry and genesis of gold deposits. Rotterdam, 1984, p. 165-182.

Stipanicic P. \& Reig A. 1957. El Complejo Porfírico de la Patagonia Extrandina y su fauna de anuros. In: Acta Geológica Lilloana, Tucumán, I: 185-297.

Uliana M. Biddle K. Phelps D., Gust D. 1985. Significado del vulcanismo y extensión mesojurńsicas en el extremo meridional de Sudamérica. Revista Asociación Geológica Argentina, Revista (XL): 231-253.

Manuscrito A-1158

Recebido em 15 de fevereiro de 2000 Revisão dos autores em 15 de maio de 2000 Revisào aceita em 20 de maio de 2000 